\title{
Revenue Seeking: A Generalization of the Theory of Tariffs-a Correction
}

Jagdish N. Bhagwati

Columbia University

T. N. Srinivasan

Yale University

In our paper on "Revenue Seeking: A Generalization of the Theory of Tariffs" (1980), we extended the theory of tariffs to include revenue seeking. We also compared tariffs with quotas, under seeking activities associated with the revenues from the former and with the rents (i.e., license premia) from the latter. We argued, among other propositions, that: (1) Revenue seeking was a zero-output activity undertaken in the presence of, and triggered by, a distortion. (2) Therefore the questions about whether and what losses it imposed were second-best (rather than first-best) questions, and thus such a seeking activity could be beneficial rather than immiserizing (i.e., the shadow price of a primary factor of production could be [sufficiently] negative). (3) Correspondingly, premium seeking ${ }^{1}$ - the "command" counterpart of the revenue-seeking phenomenon-was also a second-best phenomenon. (4) Therefore, premium seeking may also be beneficial rather than immiserizing, contrary to Krueger's (1974) argument reflecting first-best intuition. (5) The welfare cost of a quota could not, in view of the second-best nature of the problem, be measured generally (as Krueger [1974] had proposed) as the cost of an equivalent tariff (in the absence of any seeking) plus the value of the rents even if all rents were competitively sought. (6) A proper comparison of tariffs and quotas would have to compare a tariff with revenue seeking vis-à-vis a quota with premium seeking, in preference to Krueger's (1974) comparison of a quota with full premium

Thanks are due to Richard Brecher for drawing to our attention the work of Mahmudul Anam at Carleton University, who spotted the error noted in this erratum. Partial financial support by the National Science Foundation is acknowledged.

${ }^{1}$ Krueger (1974) and we, after her, called this "rent seeking," but "premium seeking" is a more appropriate term (see Bhagwati 1981; Bhagwati and Srinivasan 1981). 
seeking vis-à-vis a tariff with no revenue seeking at all. (7) In that event, tariffs and quotas could not be uniquely rank ordered in welfare terms.

All these propositions are valid except for 4 . It is impossible (except in ways which are spelled out later in this note) for premium seeking to be beneficial. The reason is that, when a quota is binding, it prevents the second-best nature of the problem from resulting in welfare improvement since the quantity constraint "bottles up" the source of positive gain that may outweigh the loss implied by the diversion of real resources to the zero-output-seeking activity.

The economic argument underlying this result is straightforward. Recall, from the theory of policy intervention to achieve a noneconomic objective that requires imports to be constrained (Johnson 1967; Bhagwati and Srinivasan 1969), that the optimal policy for this is a tariff policy. It follows that, for the level of binding imports associated with the preseeking equilibrium, the implicit tariff at that equilibrium is indeed the least-cost tariff. Any move away from that equilibrium, therefore, will be suboptimal, that is, immiserizing if imports remain fixed at the same level. Therefore premium seeking, since it does shift production and therefore the preseeking equilibrium, will always be welfare worsening. As long as imports are fixed quantitatively, therefore, premium seeking has to be immiserizing.

Note further that the result holds equally for export and import quotas when the country is small. Again, for a small country, the result will hold if the quotas are defined in foreign values rather than in pure quantity. However, even for a small country, the critical constraint on import quantity may be relaxed, opening up the possibility of beneficial premium seeking if an import quota is defined in domestic values: For, as the implicit tariff falls, the same domestic value constraint can accommodate an increasing quantity of imports.

For a large country, however, the possibility of admitting the paradox of beneficial premium seeking is enhanced. Thus, while an import quota will eliminate this possibility, an export quota does not (unless one imposes the restriction that the foreign offer curve be elastic). Thus the same export level may be compatible with more than one import quantity, and the critical import quantity constraint may not operate to exclude the paradox of beneficial premium seeking. Again, even if the import quota is fixed in foreign values, the variable terms of trade implied by the large-country assumption can relax the import constraint and open up the paradoxical possibility. ${ }^{2}$

\footnotetext{
${ }^{2}$ The important issue of comparing seeking activities triggered generally by price versus quantity distortions has been treated elsewhere by us in depth (Bhagwati and Srinivasan 1981).
} 


\section{References}

Bhagwati, Jagdish N. "Directly-Unproductive Profit-Seeking (DUP) Activities: A Theoretical Generalization." Working Paper no. 80, Columbia Univ., Dept. Econ., April 1981.

Bhagwati, Jagdish N., and Srinivasan, T. N. "Optimal Intervention to Achieve Non-economic Objectives." Rev. Econ. Studies 36 (January 1969): 27-38. . "Revenue Seeking: A Generalization of the Theory of Tariffs." J.P.E. 88, no. 6 (December 1980): 1069-87.

_. "The Welfare Consequences of Directly-Unproductive Profit-Seeking (DUP) Activities: Price versus Quantity Distortions." Mimeographed. Discussion Paper no. 375, Yale Univ., Econ. Growth Center, March 1981.

Johnson, Harry G. "The Possibility of Income Losses from Increased Efficiency or Factor Accumulation in the Presence of Tariffs." Econ. J. 77 (March 1967): 151-54.

Krueger, Anne O. "The Political Economy of the Rent-Seeking Society." A.E.R. 64 (June 1974): 291-303. 
Copyright of Journal of Political Economy is the property of University of Chicago Press and its content may not be copied or emailed to multiple sites or posted to a listserv without the copyright holder's express written permission. However, users may print, download, or email articles for individual use. 